\title{
A Comparison of Traffic Operations among Beijing and Several International Megacities
}

\author{
Yuanzhou Yang* \\ China Urban Sustainable Transport Reasearch Center, China Academy of Transportation Sciences, Beijing 100029, PR \\ China $^{\dagger}$ \\ Jing Yang \\ School of Civil and Transportation Engineering, Beijing University of Civil Engineering and Architecture, Beijing \\ 100044, PR China \\ Baohua Mao \\ Inegrated Transportation Research Center of China, Beijing Jiaotong University, Beijing 100044 China \\ Shaokuan Chen \\ Inegrated Transportation Research Center of China, Beijing Jiaotong University, Beijing 100044, PR China \\ Hongwei Guo \\ Department of Transportation Engineering, Beijing Institute of Technology, Beijing 100081, PR China \\ Received 1 August 2011; accepted 29 November 2011
}

\begin{abstract}
High-Efficient traffic system is very important for economy and society of cities. Previous studies on the traffic comparison mostly took a city as a whole, but ig nored the differences among areas inside the city. But in fact, the traffic congestion in different areas with a city is mostly different. Taking typical megacities like Beijing, London, New York, and Tokyo as objects, this paper makes cross-comparison in the traffic operation and performance based on intelligen $\mathrm{t}$ algorithm. Tr ansportation infrastructure and travel demand data are $\mathrm{d}$ iscussed and unbalanced transport system is found in Beijing because of the conflict between too much tr affic demand and defect road networks. From the aspects of traffic load, operational efficiency and safety, in dexes including traffic $v / \mathrm{c} r$ atio, average vehicle speed and accident rate are selected to assess the performance of road traffic. It is concluded that road networks of Beijin $g$ have the worst perf ormance co mpared with oth er $t$ hree m egacities and the prim ary reasons are the inappropriate distribution of utilization rate among the freeways, arterials, and local streets, and the high traffic concentration in urban area. So, several measures are recommended to improve the operation efficiency of traffic in Beijing especially for the green intelligent traffic system.
\end{abstract}

Keywords: Traffic operation; Operational efficiency; Intelligent traffic system (ITS); Traffic load; traffic safety; Intelligent algorithm.

\section{Introduction}

Just as other in ternational $\mathrm{m}$ egacities, Beij ing $\mathrm{h}$ as obtained the economy devel opment, but at the sam e time has $\mathrm{t}$ o b e co nfronted with ri gorous challenge of traffic problems. The motor traffic has been increasing sharply in last two decades ${ }^{1}$. The amount of motor and the operational Length of the subway is 1,500 thousand and $41 \mathrm{~km}$ by the end of 1990 , but by the end of 2009 it had increased to 4,000 thousand and $228 \mathrm{~km}$ in Beijing Though the $t$ raffic net works have kept im proving, the traffic co nditions still h ave a tren $\mathrm{dt} \mathrm{od}$ eteriorate. According to th e statistic $d$ ata su rveyed b y Bei jing Traffic Aut hority, there we re 27 ro ads w ith ser ious traffic jams in 1993 an d it tu rned to 99 with a sh arp increment in 1999 , after traffic $m$ anagement in 2009 ,

${ }^{*}$ Corresponding author: bjjoe@yahoo.cn 
there were still jammed roads ${ }^{2}$. Owing to the in creasing traffic jams, th e av erage sp eed of vehicle $h$ as still decreased in recently years in Beijing.

Previous studies on the traffic comparison mostly took a city as a whole, but ignored the differences among areas inside $t$ he cit $\mathrm{y}^{3,5}$. Bu $\mathrm{t}$ in fact, th $\mathrm{e} j$ ams o f traffic $\mathrm{i} n$ different area $\mathrm{s}$ with a city are $\mathrm{m}$ ostly diffe rent. F or example, Beijing covers a $\mathrm{n}$ a rea of $16,800 \mathrm{~s}$ quare kilometers in cluding $6 \mathrm{~d}$ istricts in urban area an $\mathrm{d} 8$ wards and 2 counties in near and far suburb. The traffic operation in suburb is good, especially outside the Fifth Ring Road, where the average speed reached $70 \mathrm{~km} / \mathrm{h}$ in 2009. In contrast, the roads with server traffic jams are mainly located with in the Third Ring Road. According to th e statistic $d$ ata surveyed b y Beij ing Traffic Authority, th e a verage sp eed in ar ea between the Second an $\mathrm{d}$ Th ird Ring s w as $45 \mathrm{k} \mathrm{m} / \mathrm{h}$ in 1994 and it dropped to $20 \mathrm{~km} / \mathrm{h}$ in 1996 . Even worse, it was inferior to $12 \mathrm{~km} / \mathrm{h}$ in peak period in 2003 , and in some roads. The traffic became a little better in 2006, during the AM peak period while the speed was $36.2 \mathrm{~km} / \mathrm{h}$ in highway and $23.1 \mathrm{~km} / \mathrm{h} \mathrm{i} \mathrm{nm}$ ain $\mathrm{r}$ oads ${ }^{15}$. $\mathrm{T}$ herefore, the consideration of selected area is es sential whe $n$ comparing the traffic conditions am ong several cities because the $t$ raffic performances ca $n$ be abs olutely different in different areas.

\section{Selection of Study Cities}

Only based on the cities with similar backgrounds could the com parative analysis be mean ingful. London, $\mathrm{New}$ York and Tokyo are selected as the comparison objects to Beijing for several reasons. First of all, these cities all have a 1 arge population of o ver $5 \mathrm{~m}$ illion, which we called super cities, and the traffic problems are sim ilar. Secondly, their transport systems have all types of travel modes such as auto, bus, subway, bicycle, walk etc., and the traffic com positions are relativ ely stab le. Lastly, they all $\mathrm{h}$ ave mature and successful transport system $\mathrm{s}$ after over hund reds of years development and get a lo $t$ of $\mathrm{e}$ xperiences an $\mathrm{dl}$ essons which worth bei ng learned $\mathrm{d}^{6,11-13}$.

In different areas o f a city, th e traffic con ditions are totally diverse because of the differences on population density and level of economy. It is a kind of ridiculous to compare Beijing which covers $16,800 \mathrm{~km}^{2}$ with New York which covers $776 \mathrm{~km}^{2}$. So we firstly make a brief introduction of all selected cities and confirm the area of each city in the comparison. (i) Beijing is the capital of China. The urban 6-districts, which i nclude D ongcheng, Xi cheng, $\mathrm{C}$ haoyang, Haidian, Fengtai, Shijingshan districts, is cho sen to be $t$ he com pared area. The total s quare of 6 districts is $1368 \mathrm{k} \mathrm{m}^{2}$, the $\mathrm{r}$ esident population is 9,800 thousand in 2005 .

(ii) London is the capital of England a nd the Greater London ar ea covers $1,579 \mathrm{~km}^{2}$, includi ng cent ral London $27 \mathrm{~km}^{2}$, inner London $294 \mathrm{~km}^{2}$, and outer London $1,259 \mathrm{~km}^{2}$. The resident population of Outer London is 4,500 thousand in 2005.

(iii) New York locates at the eastern coast with an area of 776 square kilometers, the resident population is 8,210 thousand at the end of 2005 . It consists of 5 Counties (M anhattan, Q ueens, Brooklyn, Bronx, Staten Island), and Ma nhattan is the ce nter of $t$ he city with an area of 60 squ are kilometers, an d its population is 1,590 thousand at the end of 2005 .

(iv) Tokyo is the capital of Ja pan and consists of 23wards, Tama area, and Island area. The area of the 23 -wards is $631 \mathrm{squ}$ are $\mathrm{k}$ ilometers, and its population is 8,460 thou sand. Th e to tal area of Tokyo is $2,187 \mathrm{sq}$ uare kilometers, an $\mathrm{d}$ its population r eached 12,560 th ousand at the end of 2005.

The selected area can be found in Table 1.

Table 1. Socio-economic index of the four cities

\begin{tabular}{ccccc}
\hline Cities & $\begin{array}{c}\text { Beijing } \\
(2005)\end{array}$ & $\begin{array}{c}\text { London } \\
(2005)\end{array}$ & $\begin{array}{c}\text { New Work } \\
(2005)\end{array}$ & $\begin{array}{c}\text { Tokyo } \\
(2005)\end{array}$ \\
\hline Comparable Area & $\begin{array}{c}\text { Urban } \\
\text { (6-disricts) }\end{array}$ & $\begin{array}{c}\text { Great } \\
\text { London }\end{array}$ & $\begin{array}{c}\text { Urban } \\
\text { (5-districts) }\end{array}$ & $\begin{array}{c}\text { Urban } \\
(23- \\
\text { yards) }\end{array}$ \\
$\begin{array}{c}\text { Square }\left(\mathrm{km}^{2}\right) \\
\text { Population }\end{array}$ & 1368 & 1580 & 785 & 631 \\
$\begin{array}{c}\text { ten thousands person) } \\
\text { Population Density } \\
\left.\text { (person } / \mathrm{km}^{2}\right)\end{array}$ & 980 & 750 & 821 & 846 \\
$\begin{array}{c}\text { GDP(billion } \$) \\
\text { Per Capita GDP(\$) } \\
\text { Per Capita Annual } \\
\text { Income }(\$)\end{array}$ & 86.73 & 284.7 & 415.9 & 802.8 \\
\hline Note: The sources of the data are from the reference & & & & \\
\end{tabular}

Note: The sources of the data are from the reference ${ }^{19-22}$.

Table 1 shows the $\mathrm{s}$ ocial-economic statistic s like area, population, GDP (Gen eral Do mestic Products), in come etc. The population densities in Beijing and London are relatively lower than that of other 2 cities because of the large number of resi dential area in sub urbs. The low population density in urban area makes residents have a good living environment but puts great commute traffic pressure on roads.

According to the statistic surv eyed by Word Bank in 2005 , Tokyo is No.1 with a GDP of 802.8 billion\$ and 
New York and Lon don are No.2 and No.3 respectively. Beijing is No.21 with the GDP of 84.44 billion\$ which is only $1 / 5$ of Tokyo's. The index 'per capita income' among th ese cities $h$ as th e sam e tren $d$ but the gaps between Beij ing and other cities are $\mathrm{m}$ uch larg er. All these data reveals th at the eco nomy of Beij ing is far behind the level of other three in ternational megacities. To so me ex tent, th e lev el of econo my decides the transport investment, so Beij ing is facing big challenge to develop tran sport system, and effective measures are necessary to implement.

\section{Traffic Infrastructure Comparison}

When it comes to traffic infrastructure, Beijing currently has been equipped wi th developed ur ban traffic networks, which is on the top among Chinese cities, but still has large gap with other developed cities.

\subsection{Size of traffic Network}

Traffic density and traffic are a ratio are always use $\mathrm{d}$ as two ind icators to esti mate the size o f traffi $\mathrm{c} n$ etwork ${ }^{2}$. The first one is the quotient of traffic leng th and city area, and the second one is the proportion of traffic construction land in total land area. As showed in Table 2 , Beijing are far behind other cities, on ly has $1 / 6$ road density of Tokyo and 1/4 road area ratio of New York.

The proportions of all types of roads in network indicate the composition of the road network. In recent decades, Beijing has paid great concentration on the ex pressway and arterial roa $d$ construction, $b$ ut ne glected the improvement of low-grade road network. As showed in Table 2, the length of freeway in Beijing has exceeded other cities, but th e proportion of low-grade road in the network is much smaller.

\subsection{Structure of traffic Network}

The proportions of all types of roads in network indicate the com position of $t$ he $t$ raffic net work ${ }^{16,17}$. In recent decades, Beiji ng ha s paid great conce ntration on the expressway and arterial road construction, but neglected the improvement of low-grade road network. As showed in Tab le 2, $t$ he leng th of freeway in Beijing has exceeded other cities, but th e proportion of low-gra de road in the network is much smaller.

\subsection{Average Width of Road}

The ga p of road a rea rat io between B eijing a nd other cities is far smaller than that of road density. Beijing has made great progress on building expressway and arterial roads, so th e average la ne width is $\mathrm{w}$ ider th an th at of other cities. In fact, it is 2.2 times of Tokyo.

\subsection{Demand and Supply Balance}

The $t$ raffic s upply of B eijing has i mproved a 1 ot. B y June 2008, 5 railway lines had been built with the total length reaching $148 \mathrm{~km}$, and $\mathrm{t}$ he $\mathrm{r}$ oad $\mathrm{l}$ ength $\mathrm{i} \mathrm{s}$ increasing year-by-year. B ut the railway network s still has 1 ow de nsity com pared with the corresponding in London, New York and Tokyo, and large proportion of travels still happen on the road networks.

The $t$ raffic de mand in $B$ eijing is as great as $i n$ ot her cities, an $\mathrm{d}$ the to tal nu mber of resident tri ps ev en $\mathrm{h}$ as exceeded Tokyo (as showed in Table 2). Though $\mathrm{m}$ otor vehicle o wned in B eijing is the smallest am ong these cities, th e m otor $t$ raffic still $h$ as great pressure on the traffic network.

As analyzed above, the traffic networks in Beijing have quite 1 ow capacity because of its size a nd structure. However, the traffic demand is g reat. It is co ncluded that $t$ he balance of demand an $\mathrm{d} s$ upply $\mathrm{c}$ an only be gotten on a very busy traffic situation.

Table 2. Traffic infrastructure of four cities

\begin{tabular}{|c|c|c|c|c|}
\hline Cities & $\begin{array}{l}\text { Beijing } \\
(2005)\end{array}$ & $\begin{array}{l}\text { London } \\
\text { (2004) }\end{array}$ & $\begin{array}{l}\text { New Work } \\
(2005)\end{array}$ & $\begin{array}{l}\text { Tokyo } \\
(2005)\end{array}$ \\
\hline $\begin{array}{l}\text { Length of road } \\
\text { network }(\mathrm{km})\end{array}$ & 4073 & 14676 & 13352 & 11845 \\
\hline $\begin{array}{c}\text { Road network } \\
\text { density }\left(\mathrm{km} / \mathrm{km}^{2}\right)\end{array}$ & 2.98 & 9.29 & 17.01 & 18.74 \\
\hline $\begin{array}{l}\text { Road area ratio } \\
\qquad\left(\mathrm{km} / \mathrm{km}^{2}\right)\end{array}$ & $5.58 \%$ & $16.4 \%$ & $23.0 \%$ & $15.9 \%$ \\
\hline $\begin{array}{l}\text { Length of expressway } \\
\qquad(\mathrm{km})\end{array}$ & 232 & 60 & - & 191 \\
\hline Proportion of local streets & $71.7 \%$ & $87.9 \%$ & - & $94.5 \%$ \\
\hline Average width of $\operatorname{road}(\mathrm{m})$ & 18.7 & 17.6 & 13.5 & 8.5 \\
\hline $\begin{array}{l}\text { Length of railway } \\
\text { networks }(\mathrm{km})\end{array}$ & 142 & 410 & 416 & 292 \\
\hline $\begin{array}{l}\text { The total travels in full } \\
\text { day(ten thousands } \\
\text { person/day, including walk } \\
\text { trips) }\end{array}$ & 2604 & 2710 & - & 2100 \\
\hline $\begin{array}{c}\text { Vehicles } \\
\text { ownership(vel/100 person) }\end{array}$ & 20.5 & 26.9 & 22.5 & 24.8 \\
\hline
\end{tabular}


In co nclusion, the traffic infrastru cture in Beijing has the following features compared with th e infrastructure in London, New York and Tokyo.

- The size of traffic networks is smallest among four cities fro $m$ th e asp ects of both ro ad density an $d$ road area ratio

- The structure of road networks is improper, for the proportion of low-class road is too low

- The a verage width of ro ads is lar ger th an others, because Beijing has taken a great effort to build the freeway and arterials

- The Traffic Pressure on tra ffic Networks is Great, For T he La rge Num ber of Metro travels and low Capacity of the traffic Network

\section{Operational Comparison}

To esti mate th e $\mathrm{p}$ erformance of $\mathrm{t}$ raffic op eration, one can begin with the traffic load, efficiency and safety. By considering the av ailability of $t$ he $d$ ata, $t$ he $v / c$ ratio, vehicle a verage speed and ac cident rate are selected a s the $\mathrm{m}$ easures to com pare traffic operation am ong different cities.

The distribution of vehicle flow has a close relationship with $t$ he 1 ocation. The ci ty cent er has a t remendous attraction to traffic fl ow, so most of the traffic jams always happens here and the volume of ve hicle flow is the highest. With respect to different traffic feature s in different areas, the B eijing is di vided i nto three areas including ce ntral ur ban area (wi thin the s econd ring), urban ar ea (betw een Second Rin $\mathrm{g}$ and Fourth Ri ng Roads), near su burb (o utside of Fourth R ing Road). New York i s al so di vided i nto cent ral ur ban a rea (Manhattan), urban area (Brooklyn, Bronx, Queens and Staten Island), nearby suburb (Nassau, etc.). London is divided into central urban area (Central London), urban area (Inner Lon don), and near subu rb (Outer Lond on). Tokyo is d ivided in to metropolitan area and 23 -wards.

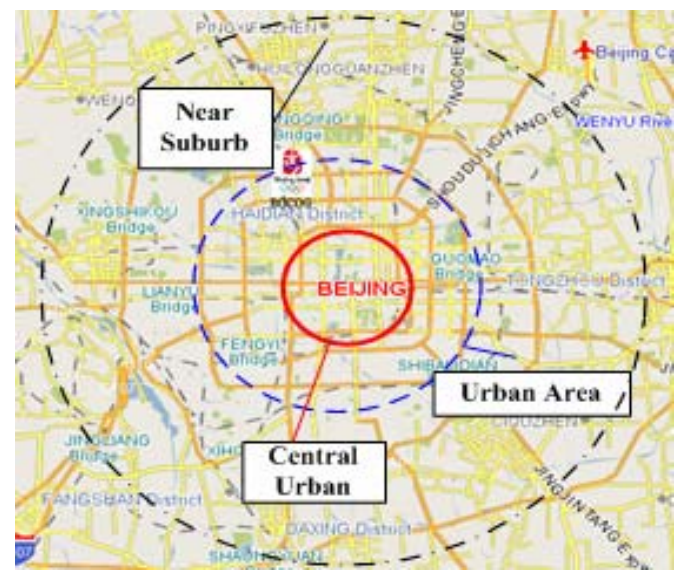

(a) Beijing

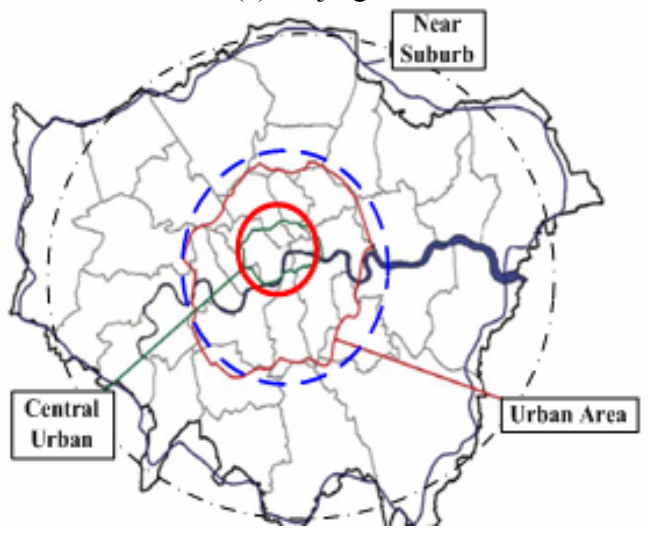

(c) London

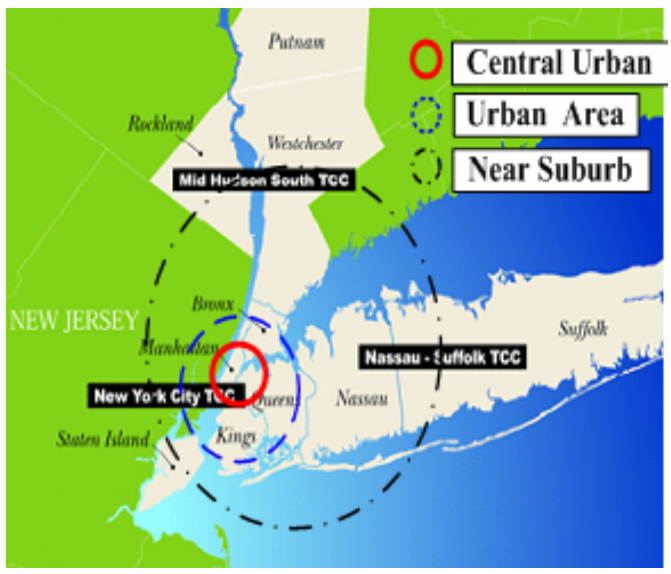

(b) New York

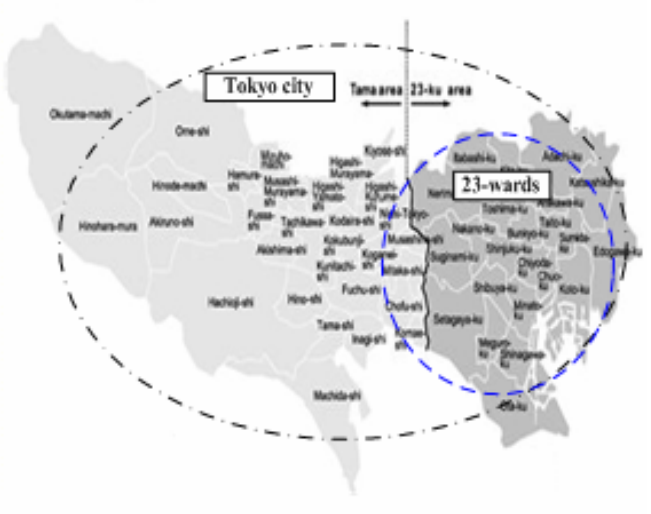

(d) Tokyo

Fig. 1. Areas division in study cities 


\subsection{Traffic Load}

The road $\mathrm{v} / \mathrm{c}$ ratio reflects the load of road network, and indicates the relationship between traffic supply an $d$ demand. It is defined by following formula.

$\mathrm{v} / \mathrm{c}$ ratio $=$ traffic volume /road carrying capacity Road v/c ratio is influenced by road location. The closer to the city cen ter, the higher the $\mathrm{v} / \mathrm{c}$ ratio is. In Beij ing, the ratio gap between central urban area a nd suburb is about $20 \%$. A s sh owed in Fig.2, in ce ntral urb an of
Beijing, the average $\mathrm{v} / \mathrm{c}$ ratio is $57 \%$ daily and $68 \%$ in peak pe riod. In area bet ween th e Seco nd and Fo urth Ring Roads, the $\mathrm{v} / \mathrm{c}$ ratio is $51 \%$ daily and $52 \%$ in peak period, and outside fourth ring, it is about $33 \%$ daily and $40 \%$ in peak period. On the contrary, the average ratio is just ar ound $30 \%$ an $d$ the distinctions am ong different areas are not so obvious in New York. The road load of Beijing is mu ch h eavier $t$ han th at of New Yo rk, especially in the city central area.

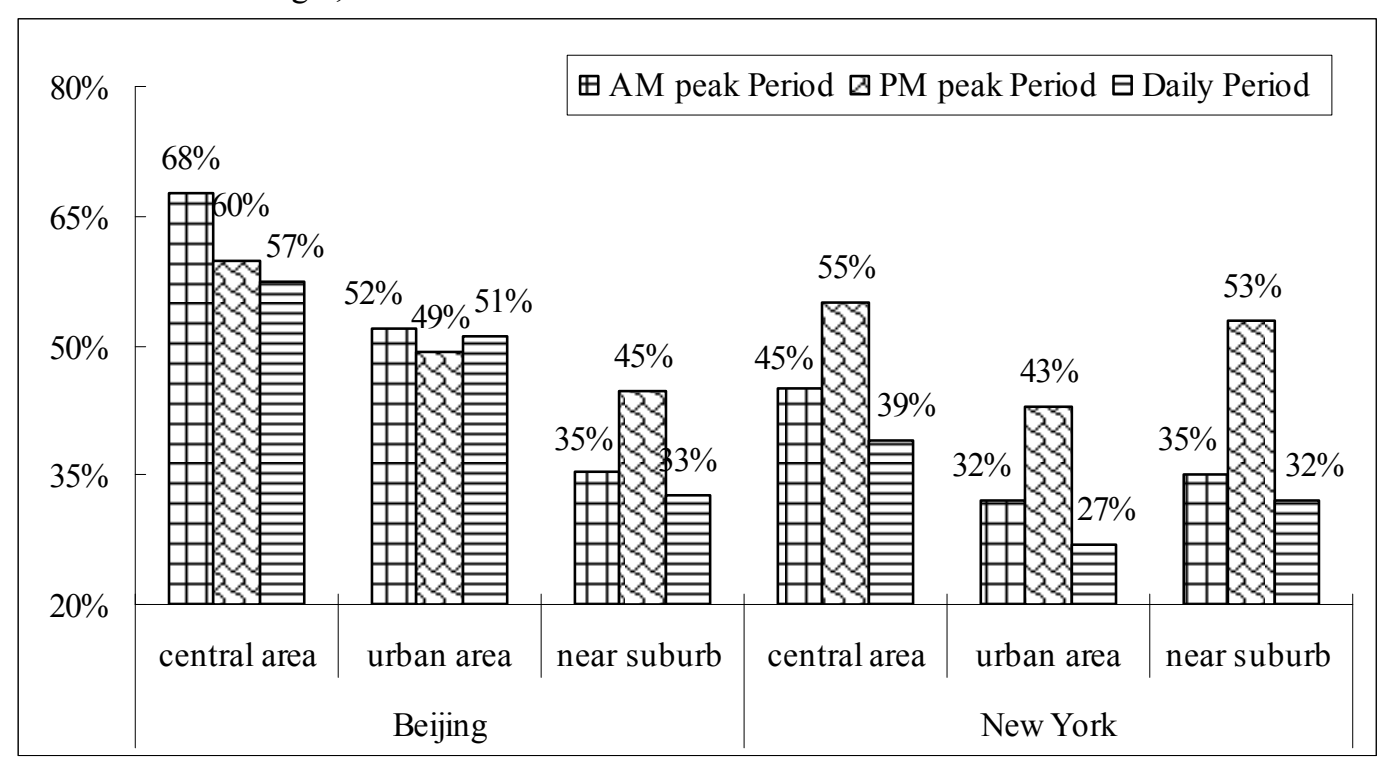

Note: The sources of the data are from the reference ${ }^{4,20,23}$

Fig. 2. V/C ratio comparison of different area in Beijing and New York

Another factor that influences the road $\mathrm{v} / \mathrm{c}$ ratio is the road grade. The $\mathrm{v} / \mathrm{c}$ ratio of freeway is the highest among all type of roads for the reasons that there are good pavements, high-speed design, free of signal interference. As illustrated in Fig.3, the following conclusions about the Beijing's road load could be drawn.

- The ave rage load is in a very hi gh le vel. The average $\mathrm{v} / \mathrm{c}$ ratios of freeway and arterial in Beijing are $35 \%$ a nd $18 \%$, which are hi gher $\mathrm{t}$ han $\mathrm{t}$ he corresponding on es in New Y ork respectively. Though the $\mathrm{v} / \mathrm{c}$ ratio of 1 ocal streets is about $5 \%$ lower, the whole road load in Beijing is higher than in New York.

- The road $\mathrm{v} / \mathrm{c}$ ratio of freew ay almost reaches $100 \%$ in $\mathrm{p}$ eak $\mathrm{p}$ eriod but the one of lo cal street is ju st about $15 \%$. The gap between them is about $70 \%$ in daily pe riod, about $\mathrm{t}$ wice $\mathrm{t}$ he gap i n Ne w York. That $\mathrm{m}$ eans the free ways in Beijing are overloa $\mathrm{d}$, and when in peak period the $\mathrm{v} / \mathrm{c}$ ratio reaches $100 \%$, the traffic fl ow will b e unstable and a little disturbance will cause traffic jam.

After analysis above, we know that the freeways in Beijing have already overload, and the load of arterial roads also reaches the top due to the influence of signallights, but the utilization rate of local street is far from being satisfied. The reasons are as follows.

- Compared with other cities, th e cap illary ro ad network which is composed by low-grade roads in Beijing has a lower density. The whole length of capillary road network is $2920 \mathrm{~km}$, much lower than $12900 \mathrm{~km}$ in London and $11193 \mathrm{~km}$ in Tokyo. 
- Too m any $\mathrm{d}$ iscontinuous and bottleneck sections exist in th e cap illary ro ad network s, so the who le capacity drop a lot.

- There are n o isolation bel ts or bar riers bet ween motor an $\mathrm{d}$ n on-motor 1 anes i $\mathrm{n} 1 \mathrm{ow}$-grade roa ds. Some sections have curb parking on non-motor lane.
So the vehicles suffer severely negative influences from the bicyclist.

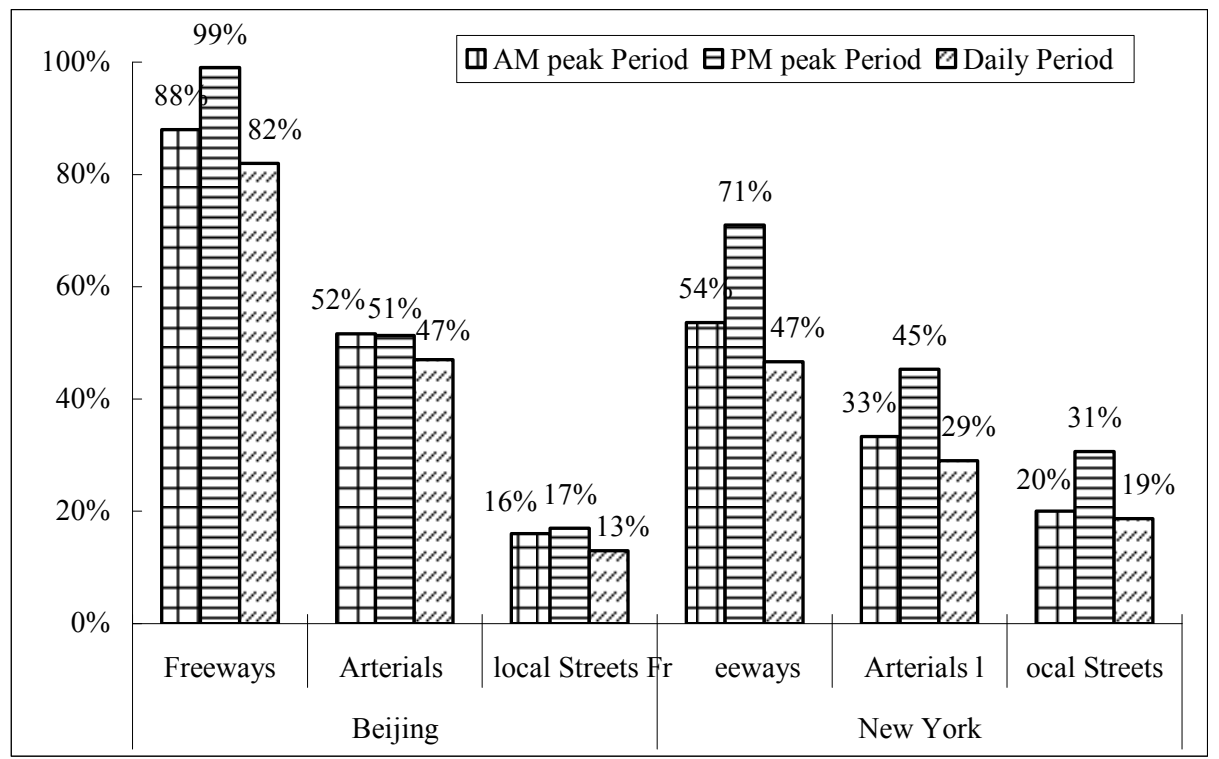

Note: The sources of the data are from the reference ${ }^{4,14,15,23}$.

Fig. 3. V/C ratio comparison of different grade road in Beijing and New York

\subsection{Operation Efficiency}

The average vehicle speed reflects the service level and operation efficiency of road. Based on surveyed data by the author's re search group and floating car dat a from
Beijing Transportation $\mathrm{R}$ esearch $\mathrm{C}$ enter ${ }^{7}$, the average speeds in different areas and grade of roads are obtained. As showed in Fig.4 and 5, the vehicle speed in Beijing has the following features.

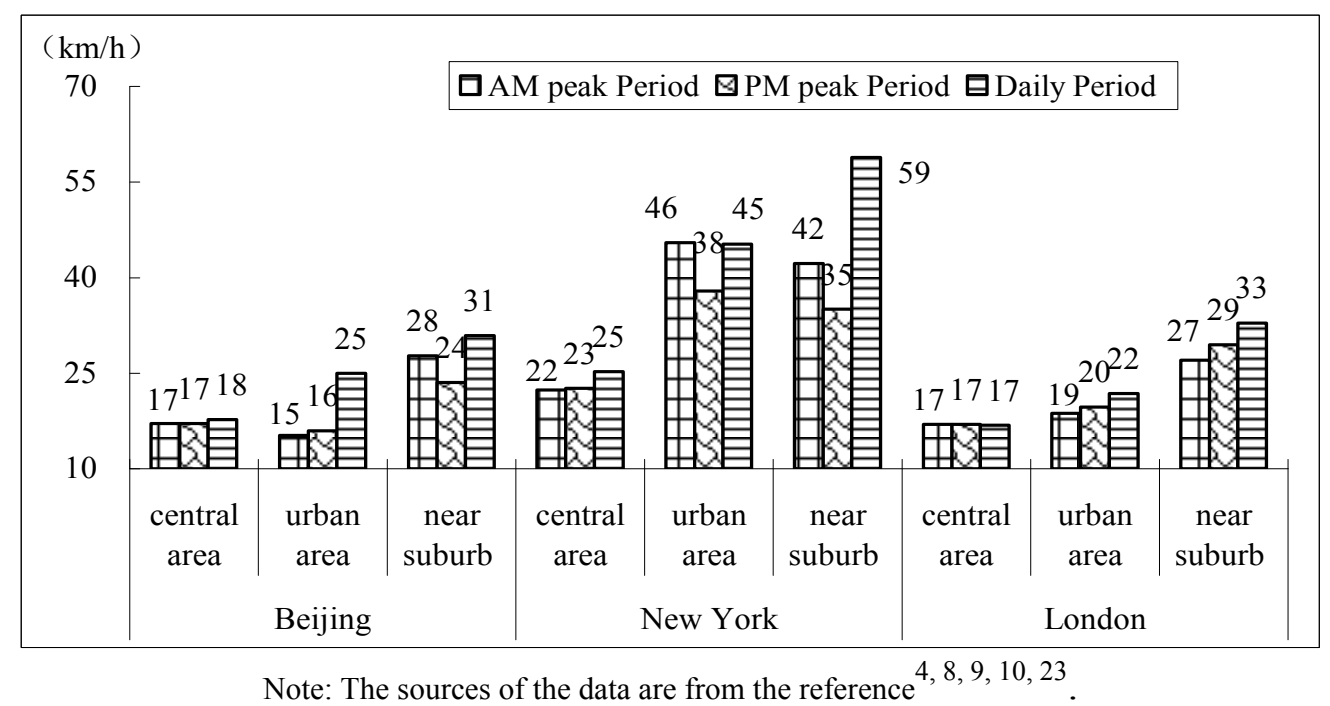

Fig. 4. Vehicle speed comparison in different grade road of Beijing, New York and London 


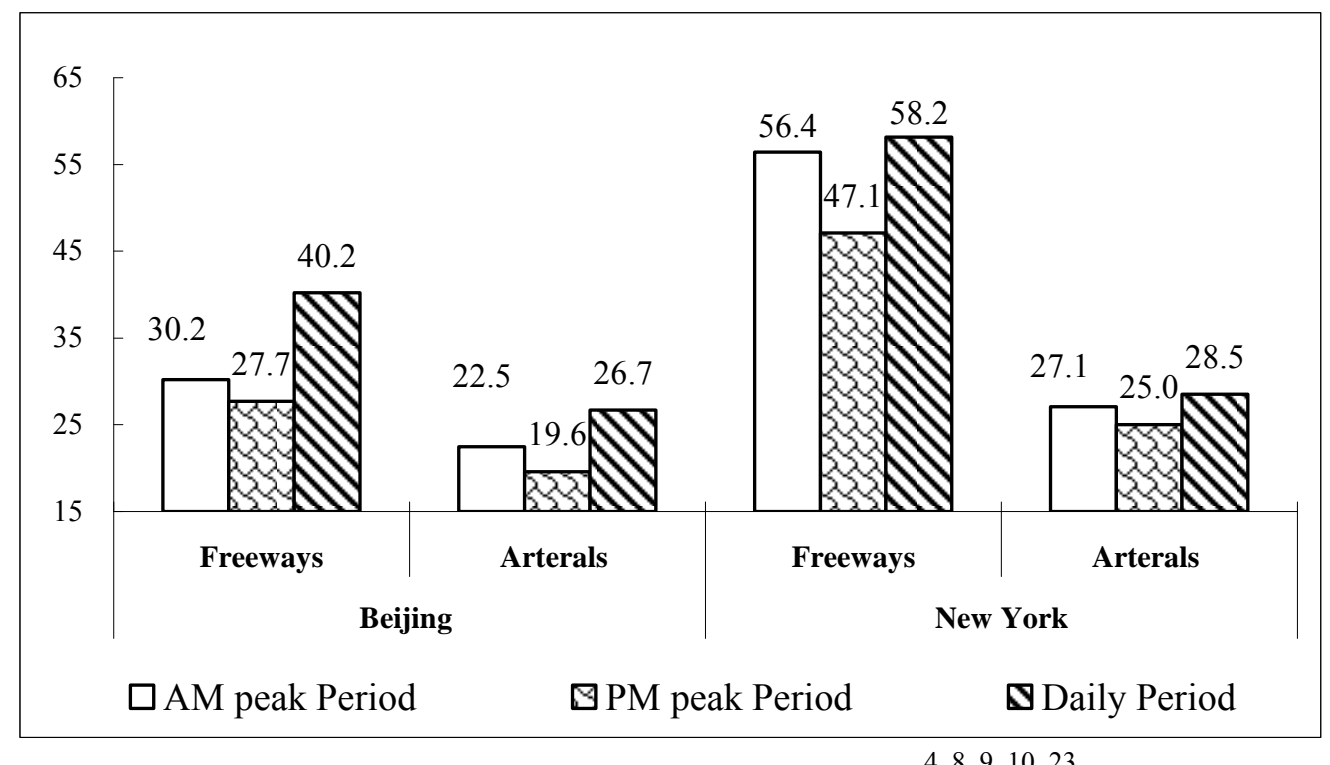

Note: The sources of the data are from the reference. $4,8,9,10,23$

Fig. 5. Vehicle speed comparison in different grade road of Beijing, New York and London

The $\mathrm{m}$ ain reason $\mathrm{s}$ lead ing to th is situ ation are alm ost same ones analyzed in last section.

- The av erage speed is lower than other cities. Fro $\mathrm{m}$ the aspect of region, in Beijing the averages speed in central area are $17.7 \mathrm{~km} / \mathrm{h}$ wh ich $\mathrm{m}$ akes the serv ice level F (re ferenced $\mathrm{f}$ rom "Hi ghway Capacity Handbook", 2000), and $22.5 \mathrm{~km} / \mathrm{h}$ in suburb which is less than $1 / 2$ of $t$ he $\mathrm{c}$ orresponding s peed in $\mathrm{Ne} \mathrm{w}$ York. From the as pect of road grade, the avera ge

\subsection{Traffic Safety}

The tr affic accid ents not on ly br ing abo ut gr eat economic loss, but als o $\mathrm{m}$ ay lead to death ${ }^{24-26}$. The traffic security is an im portant ind ex when estim ate traffic condition of a city, and also an essential in dex to the development of economy and stability of the society. The following hi storical dat a of B eijing, Tokyo, New York and L ondon show the rate of traffic accidents per hundred thousand pe ople per y ear, death toll of traffic accident per hundred thousand persons per year and the number of casu alties per hund red tho usand persons per year. The rate of traffic accidents per hundred thousand people per ye ar is $t$ he number of $t$ raffic accident per year in one hundred tho usand $p$ ersons in a city and death toll of $t$ raffic accident (the number of casualties) per hundred thousand persons per year is the nu mber of speed of arteri al ro ad is $22.5 \mathrm{~km} / \mathrm{h}$ wh ich is $5 \mathrm{k} \mathrm{m} / \mathrm{h}$ lower than in New York, and the speed of freeway is $40.8 \mathrm{~km} / \mathrm{h}$ while it is $58.2 \mathrm{~km} / \mathrm{h}$ in New York.

- There is $\mathrm{n}$ ot so o bvious switch of speed bet ween peak pe riod and $n$ on-peak period, especially in central urban area.

- The spee d ga p between central and urba $\mathrm{n}$ areas is very small, wh ile the $\mathrm{g}$ ap is abou t $20 \mathrm{~km} / \mathrm{h}$ in New York.

death pe rsons (the n umber of i njured pe rsons) in o ne hundred thousand persons in a city.

The death rate is cru cial to reflect the ex tent of harm and injury caused by traffic accidents. As showed in Fig 6 , the death tolls of these cities are all $b$ etween one and seven. Among t hem, $\mathrm{t}$ he deat $\mathrm{h} t$ oll of $\mathrm{T}$ okyo i $\mathrm{s}$ lowest(less than 2), and these of New York and London are between 2 and 4 . Beijing has the highest death toll which is as 6 times as Toky o. The reason is that there are a lot of pedestrian-vehicle an d bicyclist-vehicle accidents in Beijing which cause much higher death rate than $t$ he vehicle-vehicle accident. Additionally, it is showed in Fig 9 th at the death rates in Lo ndon, New York and Tokyo had a tr end t o d ecline y ear by year while the death rate in Beijing increased from year 2001 to year 2003 and then declined from 2003 to 2006 . The 
Road Traffic Safety Law has taken effect since 2003, so the death rate declined gradually from then on.

The rate of traffic accidents a nd the num ber of casualties by a ccidents each year re flect the freque ncy of accide nts a nd the e fficiency of emergency relief. From the Fig.6 and 7, we can get two conclusions. First of all, Compared to Tokyo, the rate of accidents and the numbers of cau salities in 100 tho usands persons are smaller in Be ijing, bu t th e death rate is higher th an Tokyo. This is due to $\mathrm{m}$ ost of accide nts data a re reported by parties in T okyo, however, in Beijing the data are recorded by the police arriving at the spot and some lightly accidents are solve d wit hout police absence, which means accidents are not fully recorded. And if the accident has some person died and it must be recorded. Therefore, the death rate in Beij ing is higher than that of T okyo. Secondly, the rate of accidents and the numbers of cau salities in 100 thousands persons in Beijing decli ned in rece nt years , es p. in 2006 respectively decreased with $51 \%$ and $41 \%$ compared to 2003. T he R oad Tra ffic Safety Law of Tokyo was modified in 2004 in view of the numbers of causalities in 100 thousands persons of Tokyo are largest that year, including no using mobile phone when driving. Then, it desirable made the rate of traffic accidents declined year by year.

The co nclusions ab out th e traffic safety in Beij ing compared between Beiji ng and ot her international metropolis are as follows.

- The rate of traffic accide nts and death in Beijing and other cities $d$ escend year b y year, wh ich indicates that these cities $h$ ave tried to improve the traffic safety and achieve success gradually.

- Compared with o ther in ternational m etropolis, the death rate in the urb an 8-wards of Beij ing is the highest, which is 6 tim es o f Tok yo. Th e traffic safety in Beijing is not optimistic, and the advanced traffic management should be brought in.

- In comparison, the rate of tra ffic accidents and the numbers of causalities in 100 thousands persons are relatively smaller than that of Tokyo, but the death rate is larg er than that of Tok yo. That is du e to the accidents in $\mathrm{B}$ eijing $\mathrm{m}$ ust be rec orded at $\mathrm{t}$ he $\mathrm{s}$ pot and some minor accidents are missed record while they are recorded by report in T okyo. In addition, Beijing's medical em ergency is inferior to Tokyo, and sometimes making some injuries died without timely medical care.

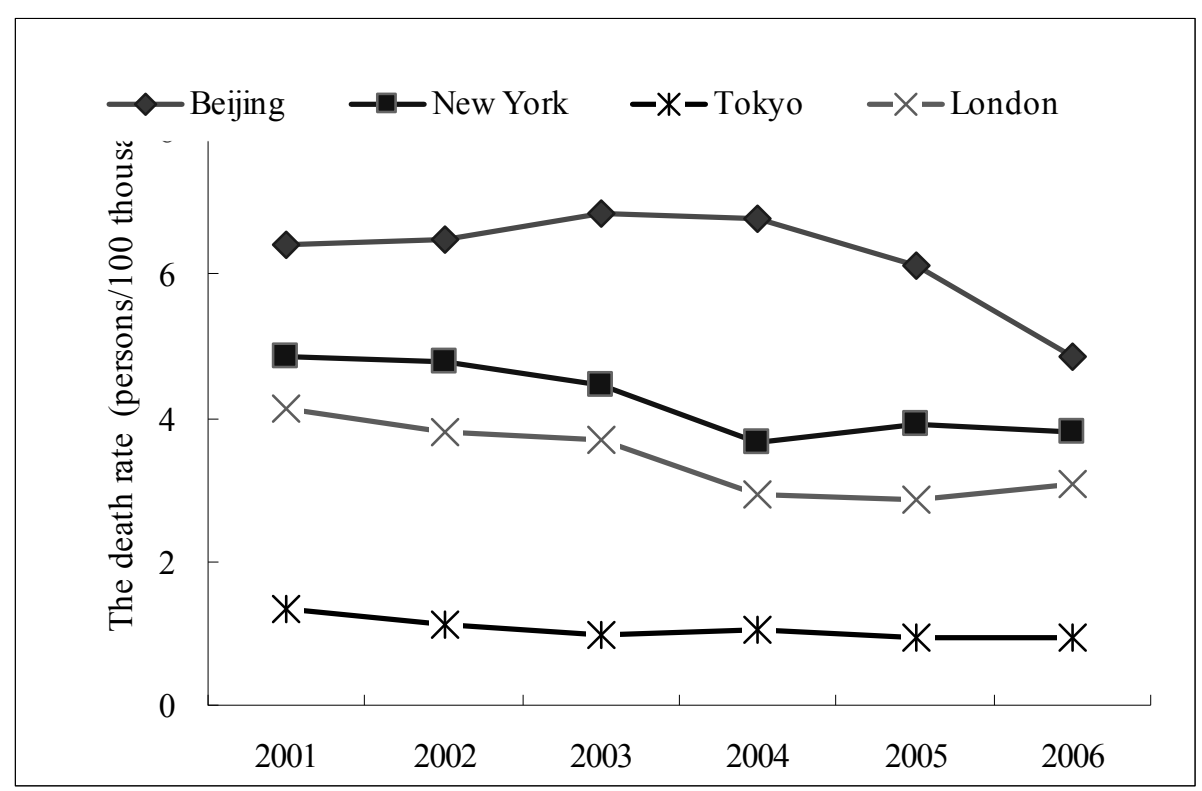

Note: The sources of the data are from the reference 4, 7, 8, 9, 10, 23 . New York's Data are from "Traffic Safety Improvements in New

York City" and New York State Data Center June, 2007. London's data are from"Transport for London"

Tokyo's Data are from internet, and the addresses are http://www.pref.ky-oto.jp/fukei/koke k/tokei/kotujiko.pdf and http://www/metro.tokyo.jp/CH-INESE/PROFILE//overviwe03.

Fig. 6. Comparison of traffic death rate 


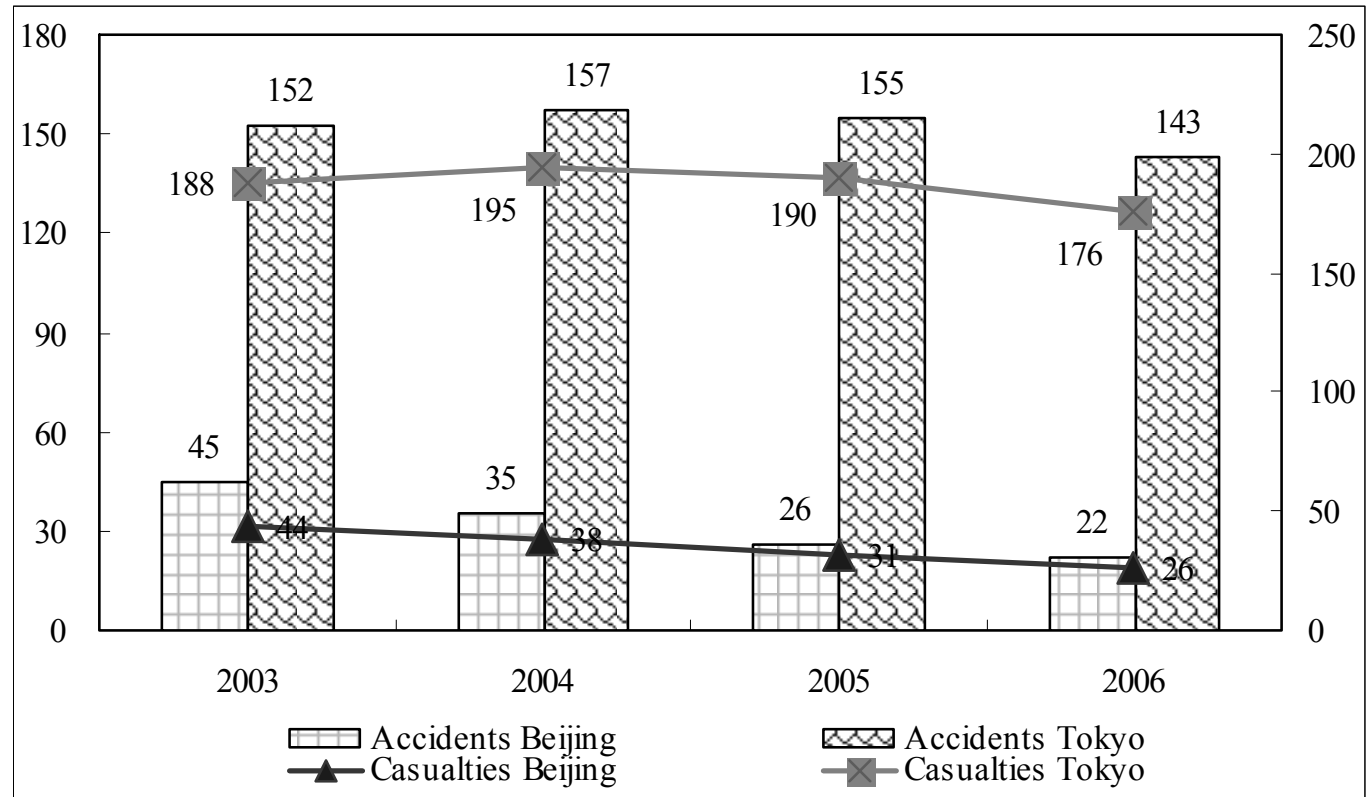

Notes: "Accidents" denotes that the rate of traffic accidents (times/100 thousand persons). "Casualties" denotes that the number of casualties (persons/100 thousands persons). The sources of the data are from the reference ${ }^{4,7,8,9,10,23}$. New York's Data are from

"Traffic Safety Improvements in New York City" and New York State Data Center, June, 2007.

Tokyo's Data are from internet, and the addresses are http://www.pref.kyoto.jp/fukei/kotu/koki_k/tokei/kotujiko.pdf and http://www.metro.tokyo.jp/CHINESE/PROFILE/overview03.htm.

Fig. 7. Comparison of safety-related indicators

\section{Conclusions}

Compared with Lo ndon, New Yor k and Tok yo, $t$ he traffic operation in Beijing has the following features.

- The l evel of e conomic devel opment of B eijing is far behind other international cities. So th e burdens on $\mathrm{c}$ onstruction $\mathrm{i}$ nvestments of $\mathrm{t}$ ransport infrastructure is heavier and the road trans port efficiency im provement should bee $\mathrm{n}$ gi ven $\mathrm{m}$ ore emphasis.

- The area of B eijing is larg e, and traffic con ditions are varied in different areas, but $\mathrm{m}$ ost commercial activities and heavy traffic areas 1 ocate in urban 8wards. According t o popu lation d ensity and function, c omparison st udy objects are chosen, which in clude Beij ing urban 6-ward s, Greater London, New York 4-counties and Tokyo 23-wards.

- Though the length of expressways and the average width of road networks in Beijing are advantageous, the length and area of roads are still lagging behind other cities, and the road structure is irrational.

- Average vehicle speed in Beijing is lower than that of other cities an $\mathrm{d} t$ he traffic pressu re on road networks is obviously higher.
- The $\mathrm{u}$ tilization rate o $\mathrm{f}$ expressways in Beijing almost reaches the up-limit $100 \%$ while the $\mathrm{v} / \mathrm{c}$ rate of low-grade roads is just less than $20 \%$. It could be attributed $t$ th $e$ in sufficient $d$ ensity, poo $r$ connectivity an d sev er horizontal in fluence of capillary road network.

- From the aspect of road traffic safety, the death rate of Beijing is also the largest one, with av erage 6-7 death per 100 thousands persons. There are a large number o f re sidents ri ding bicycle or $\mathrm{m}$ otor an $\mathrm{d}$ pedestrians without enough sense of traffic safety, which lea $\mathrm{d} t \mathrm{o}$ the acci dents are always between passer(s)-by and vehicle(s), and the high death rate.

In $\mathrm{g}$ eneral, the $\mathrm{k}$ ey $\mathrm{t} \mathrm{o}$ im prove traffic op eration $\mathrm{i} \mathrm{n}$ Beijing is equ ilibrating the traffic fl ow over the traffic network. Firstly, to indu ce the m etro traffic in cen tral urban area, the traveler can be encouraged to use public transport. TDM measures like developing transit system, charging on congestion are stro ngly recommended. Secondly, to i ncrease the utilization rate of low-class road, the capi llary road networks sh ould be i mproved, and wh en enou gh traffic $m$ oves to cap illary ro ad, the pressure on freeway a nd a rterials can be release $d$. Measures like building more low-class road to increa se 
road density, wide ning necklace roa $\mathrm{d}$ section and canceling inner-road parking to enhance the capacity are recommend. Lastly, ro ad safety is also an i mportant indicator to assess th e traffic operation. $M$ easures like making com plete and e ffective traffic 1 aws, taki ng traffic safety education to deduce the road accidents are recommended.

\section{Acknowledgements}

This research was supported in part by National Nature Science Found ation of $\mathrm{C}$ hina(NSFC) under Grant 71131001 and 71001006, and by the transportation and construction project o f sc ience an $\mathrm{dt}$ echnology of Ministry of T ransport of t he Peo ple 's Republic of China under Grant 20113182211220.

\section{References}

1. Baohua Mao, H . Q. Peng, etc. Trend Analy sis of 2009 Integrated $\mathrm{Tr}$ ansport $\mathrm{S}$ ystems of China, Journal of Transportation $\mathrm{S}$ ystems Engineering and Information Technology, 10(2) (2010) 17-22.

2. Chen, J. C ., J. F. Guo and B. H. Mao. Trip Behavior Study of Beijing OD Survey. Beijing Jiaotong University and Bei jing Transportation Re search C enter, Beijing, 2007.

3. A. Daly. Altern ative tre e log it models: Comments on A Paper of Koppelman and Wen. Transportation Research Part B, 35(8) (2001) 717-724.

4. Guo, J. F. and Y. X. Quan. Special Res earch on Beijing Traffic D evelopment Compendium. Beijing Municipal Committee of Communications, Bei jing $\mathrm{Tr}$ ansportation Research Center, China, 2007.

5. Hiroshi, S. Mo deling Urba $n$ Development and Travel Behavior for A ssessment of Land Use, $\operatorname{Tr}$ ansportation and Environmental Policies. In Proceedings of the Fourth International Conference on Traffic and Transportation Studies, Science Press. Beijing, China, 2004, pp. 88-97.

6. R. Kitamura, Y. Toshiy uki. An Analy sis of Household Vehicle Holding Durations Considering Intend ed Holding Durations. Transportation Research Part A, 34(5) (2000) 339-351.

7. X. L i and J . F . Guo. 2006 B eijing Tr ansport Annual Report. B eijing. Beijing Municipal Committee of Communications, Beijing Transportation Research Center, China, 2006.

8. London Travel Report, 2004 . http ://www.tfl.gov.uk/ assets/downloads/corporate/ London-Travel- Repor t2004-final.pdf/. Accessed Jul. 5, 2008.

9. London Travel Report, 2005 . http://www.tfl.gov.uk/ assets/downloads/corporate/ London-Travel- Repor t2005-final.pdf/. Accessed Jul. 5, 2008.

10. London Travel Report, 2006 . http://www.tfl.gov.uk/ assets/downloads/corporate/ London-Travel- Repor t2006-final.pdf/. Accessed Jul. 5, 2008.
11. C. H. Muld er. Housing Choice: Assumptions and Approaches. Journal of Housing and the Built Environment, 11(3) (1996) 209-233.

12. S. Mun, K. Konishi, etc. Optima 1 Cordon Pric ing in a Non-monocentric City. Transportation Research Part A, 39(7) (2005) 723-736.

13. R. B. Noland, K. A. S mall. Travel-time Un certainty, Departure Time $\mathrm{C}$ hoice, a nd t he $\mathrm{C}$ ost o f Mo rning Commutes. Transportation Research Record. 1995 150158.

14. Y. X. Quan Brief Introduction to the 3rd Traffic Survey of Be ijing. Beijing Municipal Committee of Communications, Beijing Transportation Research Center, China, 2006.

15. Y. X. Quan, B. H. Mao. 2009 Beijing Household Travel Survey Report. Beijing Jiao tong Universit y and Bei jing Transportation Research Center, Beijing, 2010.

16. A. Simma, K. W. Axhausen. S tructures of Co mmitment in Mode Use: A Comparison of Switzerland, Germany and Great BritainTransport Policy, 8 (2001) 279-88.

17. State and Local Policy Program. Value Pricing. Hubert H. Humphrey Institute of Public Affairs, Univ ersity o f Minnesota, Minneapolis www.hhh.umn.edu/centers/slp/vp/vp org/. Accessed, Feb. $5,2008$.

18. H. M. Tetsuro, M. Cresencio, etc. Urban Travel Behavior Characteristics of $13 \mathrm{Ci}$ ties Based on Household Interview Survey D ata. Journal of the Eastern Asia Society for Transportation Studies, 6 (2005) 23-38.

19. Tokyo Statistical Yearbook, 200 1-2006. http://www.toukei.metro.tokyo.jp/tnenkan/tn-eindex.htm/. Accessed Feb.10, 2008.

20. Beijing municipal Bureau of Statistics. Beijing Statistical Yearbook 2003-2009(Beijing , 2009). http://www.bjstats.gov.cn/xwgb/tjgb/. Accessed Feb.10, 2010.

21. Focus on London. http://www.london.gov.uk/focusonlondon/datastore.jsp. Accessed Feb.10, 2011.

22. New York State Statistical Yearbook 2005. http://www.rockinst.org/nys statistics/2005/. Acces sed Jul. 5, 2010.

23. New York Metropolitan Transportation Council Congestion $\mathrm{M}$ anagement $\mathrm{S}$ ystem 2005 Status Repor $\mathrm{t}$. http://www.nymtc.org/. Accessed Jul. 5, 2008.

24. J. Wundke, E. Ampt. Can You Influence People to Travel Less Whe $\mathrm{n}$ They Are Movi ng House? The 4th International Conference of Traffic and Transport Psychology (Nottingham, UK, 2003), pp. 5-9.

25. W. H. Wa ng, Y. Ma o, et c, Ikeuchi Ka tsushi, Driver's various information process an d multi-ru led d ecisionmaking mechanism: a fundam ental of intelligent driving shaping model, Intern ational J ournal of Computation al Intelligence Systems, 4(3) (2011) 297-305.

26. W. H. Wang, X . B. Jiang, etc Incident tree model and incident tree analysis $\mathrm{m}$ ethod for quant ified $\mathrm{r}$ isk assessment: an in-depth accident s tudy in traffi c operation, Safety Science, 48 (10) (2010) 12 48-1262. 